\title{
EVOLUTION OF GLOBAL TRADE AFTER THE CRISIS OF 2008
}

\author{
Jarosław KUNDERA \\ Wroclaw University, Institute of Economic Sciences; jarosław.kundera@uwr.edu.wroc.pl, \\ ORCID: 0000-0003-0900-7447
}

Purpose: The article deals with the problems of structural changes in the international division of labour.

Design/methodology/approach: The study used the world trade statistics and reports by WTO. Findings: The purpose of this article is to analyse the evolution of global international trade after the crisis of 2007 with a view to find out the new balance between sectors and individual partners. It concludes that after 2007, the international exchange was growing by increasing the demand for technologically advanced products, diversity and services. Trade development increased the position of New Industrial Countries in international division of labour due to global value chains.

Originality/value: The publication verifies the theories of international trade, while at the same time giving a response to the thesis concerning which theories correspond to modern reality.

Keywords: global value chains, new industrial countries, trade in technologically advanced goods.

Category of the paper: Research paper.

\section{Introduction}

The crisis of the year 2008 has sparked a new discussion between economists concerning the search for modern sources of international division of labour. Emerging trade trends after 2007 are worth examining for at least two reasons: firstly, because, through the crisis, they verify the theories of international trade, while at the same time giving a response - pointing to those theories which most correspond to the reality of actual economy. Secondly, they shed light on the shaping of the future division of labour in the global economy and the new balance between sectors and individual partners. The best verification of trade theory is of course the practice of international turnover, which concerns not only the so-called normal trading conditions, but also a period of imbalance, crisis, or time to overcome them. 
The change of traditional system in the division of labour after 2008 has affected the production activities and relationships between partners in the world economy. The crisis and global shifts of production challenge the existing assumptions beneficial to all free trade in the sense to be not only "free trade" but "fair trade", that is a trade subject to certain new regulations. Some countries even refer to the protection arguments and the defence of national interest in order to change country profitable export and import calculation and situation in their balance of payments (Salvadore, 1987, p. 13). Due to the evolution of structure of the international trade after 2007, current trade theories consider structural changes in the global economy, the position of the individual partners and companies, their international competitiveness and financial flows, and the rapid progress of information and technological development (Wydymus, Głodowska, 2013, p. 23-33).

\section{Changes in the international competitiveness of economies after 2008}

The process of overcoming the crisis in international environments relates to structural changes to increase international competitiveness that is understood as the country's ability to create the following conditions:

1. For increase of income and exports;

2. For the production of goods sold on the world market;

3. For easier financing for companies;

4. For business activities in international markets (Stankiewicz, 2002, pp. 30-31).

During the crisis, countries and businesses need to rework their production to improve productivity. If the economies are open to the outside, this overcoming of the crisis should first be followed by improving their competitive position in international trade. Generally, before 2007 crisis four categories of countries had been distinguished in terms of their competitiveness and capabilities as creators, recipients and technology donors: 1. Leaders (e.g. Switzerland, USA, EU countries, Japan, Korea, Singapure); 2. Potential leaders (e.g. Ireland, Estonia, Taiwan) 3. Dynamic followers (e.g. China, Argentina, Peru); Side countries (e.g. Algeria, Pakistan, Kenya). While leaders in the leading countries gain a competitive edge over their partners with more innovative capabilities, potential leaders try to create new products and gain access to new technologies by purchasing licenses or attracting foreign investments. In contrast, countries with less innovative capacity, the so-called dynamic followers, compete in the export of other products and services and strive to acquire foreign outlets by other means (lower production costs, prices).

Following the crisis, a new system of linkages in the international division of labour is emerging, which has a huge impact on rapid technical progress and the level of competitiveness. The innovation factor has not been weakened after 2007; on the contrary, companies spend 
enormous financial resources on research. In order to improve the market position in 2010, Toyota spent on R\&D USD 9.4 billion, Swiss company Roche - USD 8.9 billion, Microsoft USD 8.4 billion, Volkswagen - USD 8.1 billion. Especially high were the annual expenditures of companies on R\&D in the pharmaceutical industry (Pfizer, Novartis, Johnson \& Johnson) and electronics (Nokia, Samsung). In markets dominated by innovative oligopoly companies are fighting for consumers by introducing new products, constantly looking for better methods of manufacturing and conducting intensive exchange of goods at different stages of the production process. If the construction of a new aircraft costs trillions of dollars, it is unthinkable that Boeing would introduce a new type of aircraft without the possibility of its sale on the global market. Likewise, the cost of developing a new drug is now so large that pharmaceutical companies conduct vigorous export sales to cover the high cost of research. If the demand structure makes it possible to sell all product variants in all markets, the international company takes advantage of its internal trade (T. Rynarzewski, ZielińskaGłębocka, 2006, pp. 220-221).

Although the companies locate part of their production process abroad, they are trying to maintain control of such strategic activities as $R \& D$ in the country continuing their strong geographical concentration in the global economy. The U.S. spent on research close to one third of the world's outlay, i.e. 2.8\% of GDP (USD 430 billion in 2011), Europe USD 326.7 billion, (1.9 GDP), China much less - USD 174.9 billion (1.6\% of GDP) and India only USD 38 billion ( $0.8 \%$ of GDP) (Bueber, Sudt, 2012, pp. 1-3). Research and development have become such an important part of the activities of transnational corporations that in 2016 they have invested a record sum of 647 billion dollars for R\&D (two fifths of all research inputs). In the last decade, the two branches, namely the computer and health protection sector, made almost half of all the R\&D industry's expenditures. Other industries that intensively benefit from research and development expenditures are the automotive, aerospace and telecommunications industries.

The macro-economic competitiveness in international division of labour is not easy to be evaluated; the economy is classified here based on the criterion of action (competitive capacity) and effects (competitive position). The notion of competitive capacity refers to the long-term ability of the economy to cope with foreign competition. The competitive position is determined by the contribution of the national economy to international exchange: when it grows, a country improves its position, if it falls, a country loses competitiveness. (Rymarczyk, 2010, pp. 277 278).

The factors influencing international economic competitiveness are manifold and there are about 300 individual cases. Due to the very large number and diversity, these cases are grouped into four main categories: 1) Economic achievements; 2) Government efficiency; 3) Business efficiency; 4) The level of the infrastructure. The most important indicators of the country's economic performance include the size of total GDP and GDP per capita, international trade and its balance, the volume of foreign investments, direct and portfolio, employment and inflation levels. Government efficiency is assessed in terms of deficit and public debt, fiscal 
policy, central bank activity, competition policy, government spending and the quality of education. Business efficiency indicators include productivity, the functioning of labour markets, capital markets, the development of the banking sector, the internationalization of enterprises and the quality of management. Finally, the assessment of infrastructure considers factors such as quality of roads and motorways, rail and air connections, number of computers per capita, Internet development; R\&D spending, number of Nobel Prizes, life expectancy and environmental protection.

Table 1.

Ranking of the most competitive economies in the world in the years 2007-2008, 2017-2018.

\begin{tabular}{|c|c|c|c|}
\hline Countries & Years 2007-2008 & Countries & Years 2017-2018 \\
\hline 1. USA & 5.74 & 1. Switzerland & 5.86 \\
\hline 2. Switzerland & 5.61 & 2. USA & 5.85 \\
\hline 3. Denmark & 5.58 & 3. Singapore & 5.71 \\
\hline 4. Sweden & 5.53 & 4. Holland & 5.66 \\
\hline 5. Singapore & 5.53 & 5. Germany & 5.65 \\
\hline 6. Finland & 5.50 & 6. Hong Kong & 5.53 \\
\hline 7. Germany & 5.46 & 7. Sweden & 5.52 \\
\hline 8. Holland & 5.41 & 8. United Kingdom & 5.51 \\
\hline 9. Japan & 5.38 & 9. Japan & 5.49 \\
\hline 10. Canada & 5.37 & 10. Finland & 5.49 \\
\hline 11. United Kingdom & 5.30 & 11. Norway & 5.40 \\
\hline 12. Korea & 5.28 & 12. Denmark & 5.39 \\
\hline 13. Austria & 5.23 & 13. New Zealand & 5.37 \\
\hline 14. Norway & 5.22 & 14. Canada & 5.35 \\
\hline 15. France & 5.22 & 15. Taiwan & 5.33 \\
\hline 16. Taiwan & 5.22 & 16. Israel & 5.31 \\
\hline 17. Australia & 5.20 & 17. United Emirates & 5.30 \\
\hline 18. Belgium & 5.14 & 18. Austria & 5.25 \\
\hline 19. Iceland & 5.05 & 19. Luxemburg & 5.23 \\
\hline 20. Malaysia & 5.01 & 20. Belgium & 5.23 \\
\hline 21. Ireland & 4.99 & 21. Australia & 5.19 \\
\hline 22. New Zealand & 4.93 & 22. France & 5.18 \\
\hline 23. Luxemburg & 4.85 & 23. Malaysia & 5.17 \\
\hline 27. Estonia & 4.74 & 27. China & 5.00 \\
\hline 33. Czech Republic & 4.58 & 31. Czech Republic & 4.77 \\
\hline 47. Hungary & 4.35 & 39. Poland & 4.59 \\
\hline 51. Poland & 4.28 & 60. Hungary & 4.33 \\
\hline
\end{tabular}

Source: The Global Competitiveness Report 2008- 2009, 2017- 2018, World Economic Forum, Committed to Improving the State of the World, World Economic Forum, New York 2008, 2018.

The Global Competitiveness Report estimates that in the period 2007/2008-2017/2018 there was a change of leader in terms of the most competitive economy in the world (table 1). In 2017/2018, the highest competitiveness indicators were held by Switzerland (5.88), slightly ahead of the United States (5.85), which had the highest indices between 2008 and 2009. The third place was taken by Singapore (indicator 5.71), which overtook traditionally highly competitive economies like the Netherlands (5.66) and Germany (5.65). There is a decline in the ranking of the Nordic economies: Denmark (5.39), Sweden (5.52), Finland (5.49), which in 2007/2008 occupied positions from 3 to 6 . In the ten years following the crisis, except for the twenty highlighted economies, there are also some euro area member states like France (5.18), 
Spain (4.70), Portugal (4.57), or Italy, whose indebted economy fell to 47 position (4.54). Meanwhile, in the period 2007-2017, the new industrial countries (Hong-Kong, Israel) and oil countries (United Arab Emirates) were promoted to the forefront of competing economies. In 2017, China ranked 27th among the most competitive economies (5.00) just behind South Korea (5.07) but overtaking European countries such as Iceland (4.99) and Estonia (4.85). As for the countries of Central Europe, in the years 2007-2017 Poland was promoted from 51st to 39th position (indicator 4.59), Czech Republic from 33rd to 31st position (4.7), while Hungary (4.33) dropped from 47th to 60th position (4.33).

\section{Changes in the international competitiveness of economies after 2008}

The exchange of goods covers about $78 \%$ of the value of world trade, where $3 / 4$ are processed products $(40 \%$ of turnover is carried out in the electromechanical industry sector) and the services represent around $22 \%$ of the value of all international trade. In the global economy, a certain traditional division of labour has been developed, where developed countries exported most industrial goods and services with high added value and imported from developing countries raw materials and poorly processed products (agricultural products constituted $12 \%$ of global exports, fuel-9\%). This type of division of labour is subject to gradual evolution, and the crisis of the year 2007 seems to be a turning point signalling "qualitative adjustment" in the global economy. In international trade, an increasing number of high-tech, difficult to imitate products is gaining position and the share of high-tech products in total export of the processing industry represents $13.6 \%$ in the EU countries, 23.2\% in North America, $10.1 \%$ in South America, 2.5\% in the Middle East and North Africa countries (Wydymus, Głodowska, 2013, pp. 66-67).

Before the economic crisis, the EU was the largest trade bloc in the world economy with 11 of its member states being among the 30 leading exporters of goods. The EU countries (France, Italy, Germany, the United Kingdom), as well as countries such as the US, China and Japan, were among the largest exporters of the service. As far as the value of goods exported in 2007 is concerned, Germany was ahead China, the USA and Japan. Successively France, the Netherlands and Italy, and even Belgium were larger exporters than Canada, Korea and Russia (table 2). Poland was the 27th largest exporter with a similar share in global exports to India, Czech Republic and Ireland. As regards imports, the largest market in 2007 was the US, ahead of the EU 27 Member States. Both China and Japan had a much larger share of global exports than imports. Poland was the 27 th largest importer with a similar volume of imports Austria, Sweden and Switzerland. 
Table 2.

The largest exporters and importers in 2007 in billions of US dollars and their \% share in of the world's turnover

\begin{tabular}{|l|l|l|l|l|l|}
\hline Countries & export & $\mathbf{\%}$ & Countries & import & \% \\
\hline EU (27) & $1,697.8$ & 16.4 & EU (27) & 1,952 & 18.4 \\
\hline 1.Germany & $1,326.4$ & 9.5 & 1. USA & $2,020.4$ & 19.0 \\
\hline 2. China & $1,217.8$ & 8.7 & 2. Germany & $1,058.6$ & 6.7 \\
\hline 3. USA & $1,162.5$ & 8.3 & 3. China & 956.0 & 6.7 \\
\hline 4. Japan & 712.8 & 5.1 & 4. Japan & 621.1 & 4.4 \\
\hline 5. France & 553.4 & 4.0 & 5. UK & 619.6 & 4.4 \\
\hline 6. Holland & 551.3 & 4.0 & 6. France & 615.2 & 4.3 \\
\hline 7. Italy & 491.5 & 3.5 & 7. Italy & 504.5 & 3.5 \\
\hline 8. UK & 437.8 & 3.1 & 8. Holland & 491.6 & 3.5 \\
\hline 9. Belgium & 430.8 & 3.1 & 9. Belgium & 413.2 & 2.9 \\
\hline 10. Canada & 419.0 & 3.0 & 10. Canada & 389.6 & 2.7 \\
\hline 11. Korea & 371.5 & 2.7 & 11. Spain & 372.6 & 2.6 \\
\hline 12. Russia & 355.2 & 2.5 & 12. Korea & 356.8 & 2.5 \\
\hline 13. Singapore & 299.3 & 2.1 & 13. Mexico & 296.3 & 2.1 \\
\hline 14. Mexico & 272.0 & 2.0 & 14. Singapore & 263.2 & 1.8 \\
\hline 15. Taiwan & 246.0 & 1.8 & 15. Russia & 223.4 & 1.6 \\
\hline 16. Spain & 241.0 & 1.7 & 16. Taiwan & 219.6 & 1.5 \\
\hline 17. S. Arabia & 234.2 & 1.7 & 17. India & 216.6 & 1.5 \\
\hline 18. Malaysia & 176.2 & 1.3 & 18. Turkey & 170.1 & 1.2 \\
\hline 19. Emirates & 173.0 & 1.2 & 19. Australia & 165.3 & 1.2 \\
\hline 20. Switzerland & 172.1 & 1.2 & 20. Poland & 162.7 & 1.1 \\
\hline 21. Sweden & 169.1 & 1.2 & 21. Austria & 162.4 & 1.1 \\
\hline 22. Austria & 162.9 & 1.2 & 22. Switzerland & 161.2 & 1.1 \\
\hline 23. Brazil & 160.6 & 1.2 & 23. Sweden & 151.3 & 1.1 \\
\hline 24. Thailand & 153.1 & 1.1 & 24. Malesia & 147.0 & 1.0 \\
\hline 25. India & 145.3 & 1.0 & 25. Thailand & 140.8 & 1.0 \\
\hline 26. Australia & 141.3 & 1.0 & 26. Emirates & 132.0 & 0.9 \\
\hline 27. Poland & 138.8 & 1.0 & 27. Brazil & 126.6 & 0.9 \\
\hline 28. Norway & 136.4 & 1.0 & 28. Czech Rep. & 117.9 & 0.8 \\
\hline 29. Czech Rep. & 122.4 & 0.9 & 29. Denmark & 99.6 & 0.7 \\
\hline 30. Ireland & 121 & 0.9 & 30. Hungary & 95.0 & 0.7 \\
\hline Sourc: Inanal & 12.9 & &
\end{tabular}

Source: International Trade Statistics, World Trade Organization 2008.

After the economic crisis, China was promoted to the largest exporter in the global economy with an export value of USD 2,263 billion in 2017 (excluding the export of Hong Kong). If we compare the data from table No. 2 and 3, they show that China has overtaken the EU with the value of external exports - USD 2,122 billion and the US with an export of USD 1,547 billion. In 2017 Chinese exports exceeded half of Germany's exports (1,448 billion dollars) and three times of Japan's exports (698 billion dollars). In the period 2007-2017 the promotion of other Asian economies is also seen in their participation in global export: Korea from 11th positions in 2007 (371 billion - 2.7\% of world exports) went to 7th position in 2017 (574 billion $-4.1 \%$ of world exports), the economy of India from 25 th position ( 145.3 billion $-1 \%$ ) in 2007 to 21 st positions ( 298 billion $-1.7 \%$ ), and Vietnam holds the 28th position in world trade with export volumes of 214 billion (1.2\% of global exports). The countries of the Eastern Europe have slightly changed their position in global exports between 2007-2017: Poland was promoted from 27 th $\left(1 \%\right.$ of global exports) to $23^{\text {rd }}$ position (1.3\% of global exports), the Czech Republic maintained 29th place among the largest exporters (1\% of global exports), 
while Russia dropped from 12 th position (2.5\% in 2007) to the 17 th in $2017(2.0 \%)$. As a result of the decrease in crude oil prices, Saudi Arabia was also reduced from 17th $(1.7 \%)$ to 25 th place $(1.2 \%)$.

Table 3.

The largest exporters and importers in billions of US dollars and their \% participation in the world's turnover in 2017 year

\begin{tabular}{|c|c|c|c|c|c|}
\hline Countries & export & $\%$ & Countries & import & $\%$ \\
\hline 1. China & 2,263 & 16.8 & 1. USA & 2,409 & 16.9 \\
\hline 2. UE & 2,122 & 15.2 & 2. UE & 2,097 & 14.7 \\
\hline 3. USA & 1,547 & 11.1 & 3. China & 1,842 & 12.9 \\
\hline 4. Germany & 1,448 & 8.2 & 4. Germany & 1,167 & 6.5 \\
\hline 5. Japan & 698 & 3.9 & 5. Japan & 672 & 3.7 \\
\hline 6. Netherlands & 652 & 3.7 & 6. UK & 644 & 3.6 \\
\hline 7. Korea & 574 & 3.2 & 7. France & 625 & 3.5 \\
\hline 8. Hong Kong & 550 & 3.1 & 8. Hong Kong & 590 & 3.3 \\
\hline 9. France & 535 & 3.0 & 9. Netherlands & 574 & 3.2 \\
\hline 10. Italy & 506 & 2.9 & 10. Korea & 478 & 2.7 \\
\hline 11. UK & 445 & 2.5 & 11. Italy & 453 & 2.5 \\
\hline 12. Belgium & 430 & 2.4 & 12. India & 447 & 2.5 \\
\hline 13. Canada & 421 & 2.4 & 13. Canada & 442 & 2.5 \\
\hline 14. Mexico & 409 & 2.3 & 14. Mexico & 432 & 2.4 \\
\hline 15. Singapore & 373 & 2.1 & 15. Belgium & 403 & 2.2 \\
\hline 16. Russia & 353 & 2.0 & 16. Singapore & 328 & 1.8 \\
\hline 17. Spain & 321 & 1.8 & 17. Switzerland & 269 & 1.5 \\
\hline 18. Taiwan & 317 & 1.8 & 18. Emirates & 268 & 1.5 \\
\hline 19. Switzerland & 300 & 1.7 & 19. Taiwan & 259 & 1.4 \\
\hline 20. India & 298 & 1.7 & 20. Russia & 238 & 1.3 \\
\hline 21. Thailand & 237 & 1.3 & 21. Turkey & 234 & 1.3 \\
\hline 22. Poland & 231 & 1.3 & 22. Poland & 230 & 1.3 \\
\hline 23. Australia & 231 & 1.3 & 23. Australia & 229 & 1.3 \\
\hline 24. S. Arabia & 218 & 1.2 & 24. Thailand & 223 & 1.2 \\
\hline 25. Malaysia & 218 & 1.2 & 25. Vietnam & 212 & 1.2 \\
\hline 26. Brazil & 218 & 1.2 & 26. Malaysia & 195 & 1.1 \\
\hline 27. Vietnam & 214 & 1.2 & 27. Austria & 176 & 1.0 \\
\hline 28. Czech Rep. & 180 & 1.0 & 28. Czech Rep. & 162 & 0.9 \\
\hline 29. Indonesia & 169 & 1.0 & 29. Brazil & 157 & 0.9 \\
\hline 30. Austria & 168 & 0.9 & 30. Indonesia & 157 & 0.9 \\
\hline
\end{tabular}

Source: World Trade Statistical Review 2018, WTO, 2108.

As regards the evolution of imports in the post-crisis period after 2007, the US (USD 2,251 billion $-16.9 \%$ of the world import) remained the largest market in the world economy, ahead of the EU (USD 2,097 billion - 14.7\%) and China (USD 1,842 billion - 12.9\%). In the period of 2007-2017 the importance of the outlets of countries such as Korea (10th position in global imports) has increased (USD 478 billion $-2.7 \%$ of global import), India held12th position (USD 447 billion - 2.5\% of global import), Mexico - 14th position (USD 432 billion $-2.5 \%$ of world import), United Arab Emirates (USD 268 billion - 1.5\% of the world import), Thailand (share increase from $1.0 \%$ to $1.2 \%$ ) and Vietnam (1.2\%). Poland and the Czech Republic have maintained their positions in global imports, while Russia's role has declined from 15 th place in 2007 (USD 223 billion $-1.6 \%$,) to $23^{\text {rd }}$ position in 2017 (USD 191 billion - 1.3\%). Sweden, Denmark and Hungary fell outside the top thirty largest importers. 
Before the crisis, the international division of labour was based upon the same proportion of exchanges: the so-called Ricardo' goods (fuels and other raw materials, food), Heckscher Ohlin' goods (standardized goods) as well as goods of higher added value (technologically advanced). As seen from tab. no. 4, among the most important products mentioned in 2007 there were both: fuel - USD 2,862 billion, non-ferrous metals - USD 360 billion, ore and minerals - USD 308 billion, agricultural products - USD 1,114 billion, standardized goods: clothes - USD 362 billion, household items - USD 254 billion and higher added value products: telecommunications equipment - USD 1,561 billion, cars - USD 1,234 billion, chemicals USD 1,279 billion. Economic prosperity propelled particularly the exchange of crude oil, iron, steel and non-ferrous metals. In the second place of international trade were the technologically advanced goods, but the marketing of such goods as pharmaceuticals and the integrated circuits had roughly the same value in 2007 as the exchange of labour-intensive products (clothes).

\section{Table 4.}

Key products in international trade in 2007

\begin{tabular}{|ll|}
\hline Goods Exchange value in billions of USD \\
\hline 1. & Fuel 2,862 \\
\hline 2. & Telecommunication equipment 1,561 \\
\hline 3. & Cars 1,234 \\
\hline 4. & Chemicals 1,279 \\
\hline 5. & Food 1,114 \\
\hline 6. & Iron and Steel 587 \\
\hline 7. & Pharmaceuticals 427 \\
\hline 8. & Circuits 417 \\
\hline 9. & Clothes 362 \\
\hline 10. & Non-ferrous metals 360 \\
\hline 11. & Ores and other minerals 308 \\
\hline 12. Household 254 \\
\hline 13. Other resources 228 \\
\hline
\end{tabular}

Source: International Trade Statistics, World Trade Organization 2008.

As regards the structure of global exports in 2016 (table 5), the leading positions are held primarily by high-tech products. Although crude oil remains the most important commodity in international trade (USD 786.3 billion), we can see the promotion in the world export of goods such as telephone equipment (USD 532.2 billion), integrated circuits (516.7 billion), drugs (322.1 billion), computers (320.4 billion) and solar panels (112 billion). Important world trades remain: cars (672.9 billion), automobile parts (349.2 billion), trucks (113.4 billion). Attention is also given to the increasing importance of the circulation of health-related goods: medicines (322.1 billion) and blood (127.6 billion). In foreign purchases you can see a high value of luxury goods: export of gold - USD 297.1 billion, Diamonds - USD 121.1 billion, jewellery USD 97.7 billion. Among the 20 most important products exported abroad were not the labourintensive goods (clothes) or intensive goods (iron and steel) and different types of agricultural crops. 
Table 5.

Structure of world trade in 2016

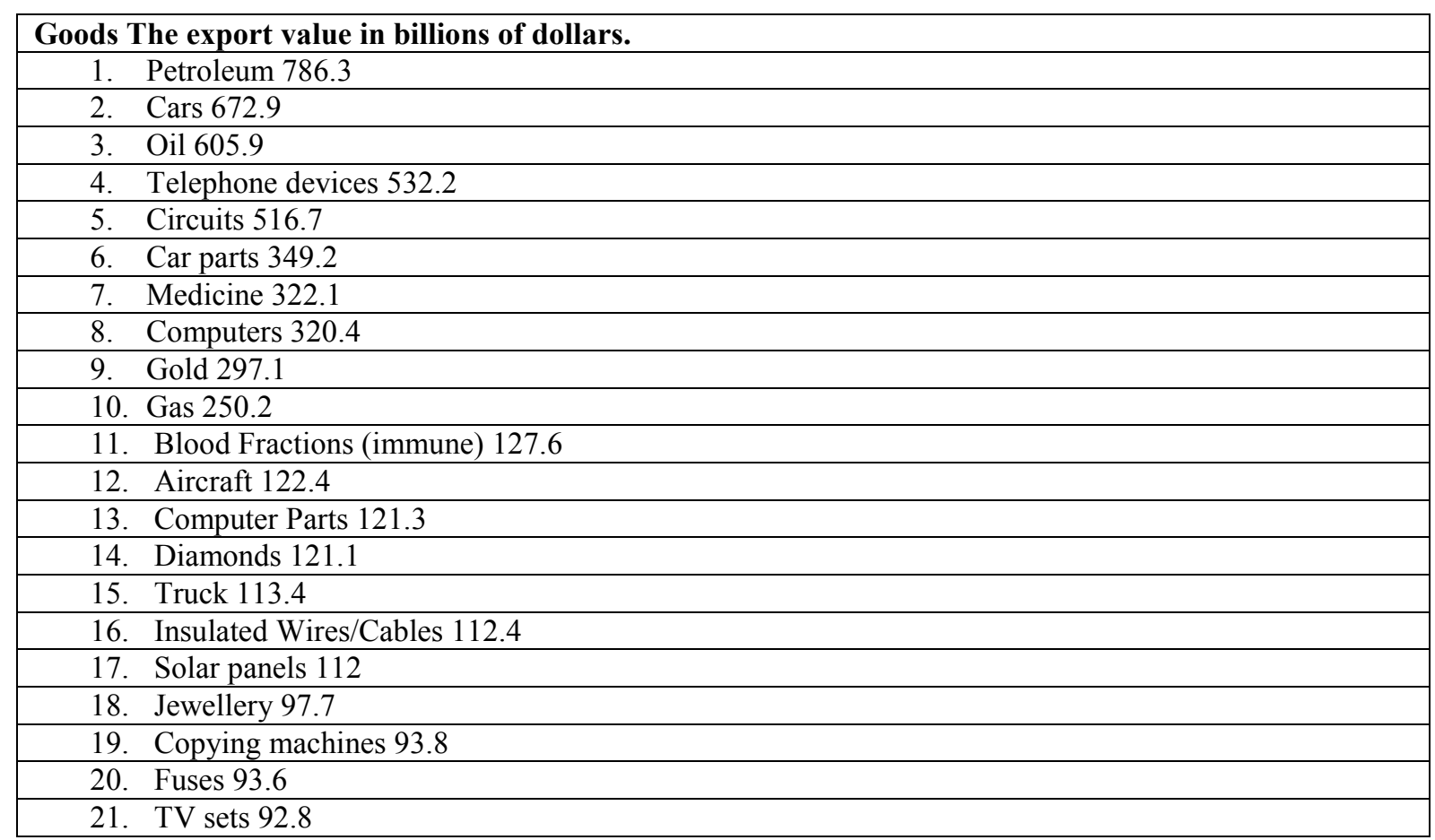

Source: International Trade Statistics, World Trade Organization 2016.

Although the growth of agricultural crops has yielded to the development of trade in industrial goods and services, the global export of agricultural crops has reached a value of USD 1,765 billion in 2017. That year the largest exporter of agricultural crops remained the EU (647 billion), considering the total export to the outside and within the EU. If we omit the exchange in the European single market, the US (163 billion) is a larger exporter of agricultural goods from the EU. In the years 2010-2017 also the role of Brazil's agricultural exports (USD 80 billion), China (USD 79 billion), Indonesia (USD 49 billion) increased. By contrast, Canada's share of the global exports decreased from $6.3 \%$ to $3.8 \%$, Australia's from $3 \%$ to $2.2 \%$ (World Trade 2018), while the EU crops exports grew annually by $2 \%$, the US by $3 \%$, Argentina by $0 \%$, China by $7 \%$ and India by $9 \%$, after the crisis. As regards imports of agricultural products, it is apparent from the emerging trend of declining participation of developed countries in the world trade. After 2007, China's role in global imports of agricultural crops has grown (from 3.3\% to 9.5\%), hence the position of Asian and African developing countries in global food imports appears to be increasing. It is also worth adding that thanks to the "green revolution" exports of India outweigh the value of imports.

The economic crisis has mainly struck the global exchange of raw materials. The largest exporters of fuels and raw materials in the global economy remain to be: EU, Russia, Saudi Arabia, Australia, Canada and United Arab Emirates. However, if we omit the reciprocal exchange of EU countries, the largest exporter of raw materials and fuels in 2017 is Russia USD 196 billion (6.9\%), Saudi Arabia - 170 billion (5.4\%), then Australia - 145 billion, Canada - 113 billion, United Arab Emirates - 67 billion and Norway - 65 billion. In the years 2010- 
2015 due to the economic crisis, the export dynamics of fuels by Saudi Arabia and Russia decreased by $7 \%$ per annum, in case of Norway by $6 \%$, and Australia by $4 \%$. A decline in exports has obviously dwindled the markets of the largest importers: the U.S. annual decline in imports of raw materials and fuels was by $10 \%$, Japan $-8 \%$, EU by $5 \%$. As far as the largest importers of raw materials and fuels remain economically developed countries (the EU, USA, Japan, Korea), after the crisis, the importance of the Chinese market in imports of raw materials grew from $3.7 \%$ to $13.1 \%$, and of India from $2.4 \%$ to $4.8 \%$ (World Trade Statistics Review, 2016).

Global iron and steel exports were most affected by the world recession of 2007. In view of the declining demand and prices, the export of iron and steel was lower in all 10 of the world's top exporters. The largest exporters of iron and steel were the remaining EU Member States (USD 156 billion), China (USD 64 billion) and Japan (USD 29 billion). The biggest declines of exports hit Russia and Ukraine, the smallest concerned Brazil, which advanced from 11 th positions to 8 th on the list of world exporters. The USA is in 6th place with less export value (USD 16 billion) than Korea (USD 26 billion). The largest outlets remain the US with imports of iron and steel in the amount of USD 39 billion, EU - an external import of USD 32 billion, China - USD 20 billion (The World Trade Statistical Review, World Trade Organization, 2016, 2017).

Textiles belong to the so-called basic goods characterized by low flexibility in demand. However, these are not homogeneous goods, but differing in value in terms of performance, just like suppliers and consumers are not homogeneous. In 2015, the dominant exporter of textiles became China, whose global exports have increased to $37.4 \%$, that is USD 109 billion from $10.4 \%$ in 2000 . The crisis of the year 2007 did not prevent the development of China's exports as their value rose by $47 \%$ between 2010 and 2015. While the importance of textile exports decreases in EU, US and North Korean to respectively 6.9\% (external exports), $4.8 \%$ and $3.7 \%$, in the period of 2000-2015 the importance of India in their global exports increased from $3.6 \%$ to $5.9 \%$, and in case of Turkey from $2.4 \%$ to $3.8 \%$. It is worth noting that between 2010 and 2015 annual exports of textiles from India to the world market grew by $25 \%$ and from Turkey by $24 \%$. US and EU countries remain, of course, the biggest markets for textile exports from developing countries, although the importance of the European single market has decreased from around $1 / 3$ to $1 / 5$. The US share of global imports has remained roughly at the same level decreasing from $9.8 \%$ to $9.6 \%$ (The World Trade Statistical Review, World Trade Organization, 2016).

As with textiles, the largest supplier of clothing in the world is China with an export volume of USD 175 billion in 2015, which is 39.3\% of global export. After 2010 there was also a rise in developing countries, where the annual increase in Bangladesh exports was $12 \%$, in Vietnam $-16 \%$, India $-10 \%$ and Cambodia $-10 \%$. It is far outweighed by the dynamics of exporting EU countries which is $2 \%$ or US - 5\%, over a comparable period. Consequently, countries such as Bangladesh (3rd place), Vietnam (4th place) were promoted to the list of leading global 
exporters, and India, Turkey and Indonesia were among the top 10 exporters. When it comes to import, the largest markets for garments produced in developing countries are the developed countries: the EU (USD 170 billion), the US (USD 97 billion), Japan (USD 29 billion), although their share in global imports decreases. In the years 2010-2015 most of the imports to Korea increased by $14 \%$ to $1.7 \%$ of global imports and to China by $21 \%$ to $1.3 \%$ of global imports while the import value of Switzerland and Russia fell (The World Trade Statistical Review, World Trade Organization, 2016).

As regards higher value-added goods such as car exports, the situation of world trade is different from the division of labour in the field of basic goods. During the crisis, the decreasing share of global car exports of Japan, the USA and Canada were accompanied by an increase in exports from Mexico and Korea and new exporters such as China, Thailand, Turkey and India also emerged. Between 2010 and 2015 exports of cars fell in Japan by 2\% per annum, while other major exporters have developed exports of vehicles, like in Mexico by $12 \%$ per annum, China by $12 \%$, India by $8 \%$ and Thailand by $7 \%$. In 2017 EU countries were still the largest car exporter in the global economy - USD 738 billion, which represents $50.6 \%$ of world exports. The following biggest car exporters are Japan with USD 150 billion (10.2\% of global exports), USA - USD 135 billion (9.25\%), Mexico - USD 109 billion (7.47\%), Korea USD 64 billion (4.38\%), Canada - USD 63 billion (4.32\%), China - USD 54 billion (3.7\%), Thailand - USD 29 billion (1.9\%), Turkey - USD 24 billion (1.6\%), Brazil - USD 15 billion (1.02\%). After the crisis of 2007 there were also evolutions in global cars import, where the importance of developed countries was decreasing (EU, USA, Canada, Japan), but the market was growing in China, Saudi Arabia, Turkey and Russia (The World Trade Statistical Review, World Trade Organization, 2016, 2017).

High-tech products represent $70 \%$ of world trade in the processing industry, with telecommunications and electronic equipment being the most important commodity in this group (about $30 \%$ of turnover). However, individual countries are involved to varying degrees in the exchange of technologically advanced goods. The largest exporter of telecommunications and office equipment today is China - 592 billion US dollars, whose share in the world trade increased from 2000 to 2017 from $4.5 \%$ to $32 \%$. While global exports of this equipment are decreasing the relevance of EU external exports ( $8.7 \%$ to $4.9 \%$ ), the USA (from $15.9 \%$ to $8 \%$ ), Japan $(11.2 \%$ to $3.5 \%)$, the competitiveness of the new industrial countries is increasing: Hong Kong exports - 281 billion dollars (15.6\% of global exports in 2017), Korea - 136 billion (7.5\%), Singapore - 121 billion (6.8\%), Taiwan - 119 billion dollars (6.6\%), Mexico 67 billion dollars (3.7\%), Malaysia - 66 billion dollars (3.7\%), Vietnam - 66 billion dollars (3.7\%) (World trade 2018). As it is calculated, Asian countries provide a total of about $50 \%$ of technologically advanced products, which is related not only to the transfer of production from highly developed countries, but also to the ability to imitate innovation and dispose relevant knowledge capital (Wydymus, A. Głodowska, 2013, pp. 64-65). 
The global export of chemicals is another group of technologically advanced products, the exports of which amounted to more than 1,993 billion US dollars in 2017. The largest exporters remained EU countries ( 972 billion dollars $-49 \%$ in total) and the USA (206 billion dollars 11\%). A steady progress of exports of chemicals has been reported by China (USD 142 billion $-7 \%$ in global exports), Switzerland -100 billion dollars, Korea -70 billion dollars, Singapore -50 billion dollars and India -41 billion dollars It is worth noting that, despite the decline in crude oil turnover in the world economy, there was no noticeable decline in the value of the exchange of chemicals (except for Japan) (World Trade, 2018). Among the largest exporters, the annual exports grew between 2010 and 2015 by $3 \%$ in the EU (external exports), by $2 \%$ in the USA, by $8 \%$ in China, and by $4 \%$ in Switzerland and Korea. In the years 2010-2015 the annual import of chemicals grew in the EU by $2 \%$, in the US by $4 \%$, in China by $3 \%$, in India by $6 \%$, and in Mexico by $5 \%$. Although EU and US maintain a high position on the import of chemicals (39.5\% and $11.5 \%$ respectively) there was a growing share of China, Brazil and India in global imports of chemicals to $8.9 \%, 2 \%$ and 1.9\% (The World Trade Statistical Review, World Trade Organization, 2016).

Regarding the global export of pharmaceuticals, the dominance of European countries is maintained, which increases the advantage of competitors. External exports of EU countries increased between $2010-2015$ from $26.7 \%$ to $29.8 \%$, while Switzerland's contribution increased from $10.6 \%$ to $12.2 \%$ due to its strong competitive position. The importance of new industrial countries: India (2.6\% of global exports), China (2.5\%), Singapore (1.4\%) and Panama (0.7\%), was also growing. For example, Israel become the world's eighth largest exporter with an export volume of more than 7 billion US dollars in 2016. It is worth noting that the pharmaceuticals exchange was not actually affected by the crisis (excluding Russia), as both export and import grew in the EU (5\% and 2\%), Switzerland (6\% and $2 \%)$, China (5\% and $9 \%$ ) while in India export growth was by $14 \%$ (The World Trade Statistical Review, World Trade Organization, 2016).

Generally, it should be stressed that after the crisis of 2007, there is a change in the international division of labour due to the growing role of technologically advanced commodities exchanges and the gradual reallocation of production to the new industrial countries. The participation of these countries in the trade of high-tech goods, both on the export and import side, is a testament to the growth of their international competitiveness and the modernization of industrial structures. As technologically advanced commodities are saturated with investment in R\&D, they contribute to the building of a knowledge-based economy. A growing trade in these areas can provide evidence of the evolving structure and diffusion of knowledge in the global economy. 


\section{Turnover of services in the global economy after 2008}

The value of services turnover is lower than the exchange of goods, but their rank is steadily increasing in the modern world economy. In particular, tourism and transport services and hightech services (telecommunications, education, healthcare, advertising, tax consultancy, accountancy and accounting, etc.) are growing rapidly. The share of technologically advanced services in global export and import services is at the level of around 5\% of the turnover of all types of services.

The largest exporters of services in the 2007 were the EU countries - USD 667 billion (27.7\% of world trade), USA - 456.4 billion (18.9\%), Japan - 127.1 billion (5.3\%), China 127.1 billion (5.1\%), and India - 89.7 billion (3.7\%). Similarly, the largest importers of services in 2007 were EU - USD 544.9 billion (24\% of world imports), USA - 335.9 billion (14.8\%), Japan - 148.7 (6.6\%), China - 129.3 (5.7\%) and Korea - 82.5 (3.6\%). Among the 30 largest exporters were still: Hong Kong and Macau - territories joined to China, as well as Russia and Ukraine, and Arab Egypt, Lebanon and Morocco (table 6).

Table 6.

The largest exporters and importers of services in the world economy in 2007 according to the turnover value in the US dollars and the \% share

\begin{tabular}{|c|c|c|c|c|c|}
\hline Countries & export & $\%$ & Countries & import & $\%$ \\
\hline 1.EU (27) & 667.2 & 27.7 & 1.EU (27) & 544.9 & 24.0 \\
\hline 2.USA & 456.4 & 18.9 & 2.USA & 335.9 & 14.8 \\
\hline 3.Japan & 127.1 & 5.3 & 3.Japan & 148.7 & 6.6 \\
\hline 4.China & 121.7 & 5.1 & 4.China & 129.3 & 5.7 \\
\hline 5.India & 89.7 & 3.7 & 5.Korea & 82.5 & 3.6 \\
\hline 6.Hong Kong & 82.7 & 3.4 & 6.Canada & 80.3 & 3.5 \\
\hline 7.Singapur & 67.3 & 2.8 & 7.India & 77.2 & 3.4 \\
\hline 8.Korea & 61.5 & 2.6 & 8.Singapore & 70.1 & 3.1 \\
\hline 9.Switzerland & 61.5 & 2.6 & 9.Russia & 57.8 & 2.5 \\
\hline 10.Canada & 61.4 & 2.6 & 10.Hong Kong & 41.0 & 1.8 \\
\hline 11.Norwey & 40.7 & 1.7 & 11.Norwey & 38.6 & 1.7 \\
\hline 12.Australia & 39.7 & 1.6 & 12.Australia & 38.2 & 1.7 \\
\hline 13.Russia & 39.1 & 1.6 & 13.Thajland & 38.0 & 1.7 \\
\hline 14.Taiwan & 30.9 & 1.3 & 14.Taiwan & 35.3 & 1.6 \\
\hline 15.Thailand & 28.8 & 1.2 & 15.Brasil & 34.8 & 1.5 \\
\hline 16.Turkey & 28.2 & 1.2 & 16.Switzerland & 33.9 & 1.5 \\
\hline 17.Malesja & 28.2 & 1.2 & 17.SaudiArabia & 30.6 & 1.3 \\
\hline 18.Brasil & 22.6 & 0.9 & 18.Emirates & 28.1 & 1.2 \\
\hline 19.Israel & 21.1 & 0.9 & 19.Malezja & 27.8 & 1.2 \\
\hline 20.Egypt & 19.7 & 0.8 & 20.Mexico & 24.0 & 1.1 \\
\hline 21.Mexico & 17.8 & 0.7 & 21.Indonesia & 23.3 & 1.0 \\
\hline 22.Macau & 14.5 & 0.6 & 22.Israel & 17.8 & 0.8 \\
\hline 23.Ukraina & 13.6 & 0.6 & 23.SouthAfrica & 16.3 & 0.7 \\
\hline 24.SouthAfrica & 13.2 & 0.5 & 24.Turkey & 14.1 & 0.6 \\
\hline 25.Croatia & 12.6 & 0.5 & 25.Nigeria & 13.9 & 0.6 \\
\hline 26.Liban & 12.5 & 0.5 & 26.Egypt & 13.1 & 0.6 \\
\hline 27. Indonesia & 12.0 & 0.5 & 27.Kazachstan & 11.3 & 0.5 \\
\hline 28.Morocco & 11.7 & 0.5 & 28.Ukraine & 10.8 & 0.5 \\
\hline 29.Argentina & 9.8 & 0.4 & 29.Argentyna & 10.5 & 0.5 \\
\hline 30.NewZeland & 9.0 & 0.4 & 30.Kuwait & 10.4 & 0.5 \\
\hline
\end{tabular}

Source: The World Trade Statistical Review. World Trade Organization, 2016. 
After 2007, there were no major changes to the leading exporters and importers of services (table 7). The largest service exporters in 2017 were still EU countries - 979 billion US dollars (24.4\%), USA - 762 billion dollars (19.0\%), China - 226 billion dollars (5.7\%), Japan - 180 billion dollars (4.5\%), India - 179 billion dollars (4.5\%) and the biggest importers were the EU - 793 billion dollars (20.1\%), USA - 516 billion dollars (13.1\%), China - 464 billion dollars (11.7\%), Japan - 189 billion dollars (4.8\%), Singapore - 171 billion dollars (4.3\%), India 150 billion dollars (3.8\%). Among the largest of the thirty exporters are some new countries such as: United Arab Emirates - 70 billion dollars (1.7\%), Philippines - 36 billion dollars (0.9\%), Saudi Arabia - 17 billion dollars (0.4\%), Qatar - 17 billion dollars (0.4\%), South Africa -15 billion dollars $(0.4 \%)$. After a period of crisis, there is also a rise in new industrial and petroleum countries in terms of service imports, which has increased the position of Singapore, India, the United Arab Emirates, Kuwait and Qatar. Among the thirty largest exporters and importers of services there is no country from the Central and Eastern Europe region.

Table 7.

The largest exporters and importers of services in billions of US dollars and in \% of their global turnover in 2017 year

\begin{tabular}{|l|l|l|l|l|l|}
\hline Countries & Export & $\mathbf{\%}$ & Countries & Import & \% \\
\hline 1.EU (27) & 979 & 24.4 & 1.EU (27) & 793 & 20.1 \\
\hline 2.USA & 762 & 19.0 & 2.USA & 516 & 13.1 \\
\hline 3.China & 226 & 5.7 & 3.China & 464 & 11.7 \\
\hline 4.Japan & 180 & 4.5 & 4.Japan & 189 & 4.8 \\
\hline 5.India & 179 & 4.5 & 5.Singapore & 171 & 4.3 \\
\hline 6.Singapore & 165 & 4.1 & 6.India & 150 & 3.8 \\
\hline 7.Switzerland & 122 & 3.0 & 7.Korea & 120 & 3.0 \\
\hline 8.Hong Kong & 104 & 2.6 & 8.Canada & 105 & 2.7 \\
\hline 9.Korea & 86 & 2.2 & 9.Switzerland & 104 & 2.6 \\
\hline 10.Canada & 86 & 2.1 & 10.Russia & 87 & 2.2 \\
\hline 11.Thailand & 75 & 1.9 & 11.Emirates & 84 & 2.1 \\
\hline 12.UnitedEmirates & 70 & 1.7 & 12.HongKong & 77 & 2.0 \\
\hline 13.Australia & 65 & 1.6 & 13.Australia & 66 & 1.7 \\
\hline 14.Russia & 58 & 1.4 & 14.Brazil & 66 & 1.7 \\
\hline 15.Taiwan & 45 & 1.2 & 15.SaudiArabia & 53 & 1.3 \\
\hline 16.Israel & 44 & 1.1 & 16.Taiwan & 53 & 1.3 \\
\hline 17.Turkey & 44 & 1.1 & 17.Norway & 49 & 1.2 \\
\hline 18.Macao & 38 & 1.0 & 18.Thailand & 46 & 1.2 \\
\hline 19.Norway & 38 & 0.9 & 19.Malaysia & 42 & 1.1 \\
\hline 20.Malaysia & 37 & 0.9 & 20.Mexico & 37 & 0.9 \\
\hline 21.Philippines & 36 & 0.9 & 21.Indonesia & 32 & 0.8 \\
\hline 22.Brasil & 34 & 0.8 & 22.Qatar & 30 & 0.8 \\
\hline 23.Mexico & 27 & 0.7 & 23.Israel & 29 & 0.7 \\
\hline 24.Indonesia & 24 & 0.6 & 24.Kuwait & 28 & 0.7 \\
\hline 25.Egypt & 19 & 0.5 & 25.Philippines & 26 & 0.7 \\
\hline 26.Qatar & 17 & 0.4 & 26.Argentina & 24 & 0.6 \\
\hline 27.Saudi Arabia & 17 & 0.4 & 27.Turkey & 23 & 0.6 \\
\hline 28.New Zealand & 16 & 0.4 & 28.Vietnam & 17 & 0.4 \\
\hline 29.Morocco & 15 & 0.4 & 29.Nigeria & 17 & 0.4 \\
\hline 30.South Africa & 15 & 0.4 & 30.Egypt & 16 & 0.5 \\
\hline S0ure: Wora & 0.4 & Sta & \\
\hline
\end{tabular}

Source: World Trade Organization, Press/793 Trade Statistics and Outlook, 12 April 2018. 
The role of transport services is growing in the world trade with the development of trade flows. After 2010 exports of transport services increased moderately in 6 of the top 10 exporters, excluding Japan $(-3 \%)$, Korea $(-4 \%)$, Canada $(-1 \%)$ and the EU, where the value of exports of these services remained at the same level. The EU countries and the US remain the largest exporters of transport services. Among the 10 largest exporters of transport services are both new industrial countries: Singapore (5.4\% of world export share in 2016), China (4.4\%), Turkey (1.6\%), India (1.6\%) and highly developed countries: Japan (5.1\%), Norway (2\%), Canada (1.4\%), Switzerland (1.2\%). Equally diverse as in case of exports are the recipients of transport services, which are both economically developed countries: EU (30\% of world imports), the USA (13.1\%), South Korea (2.7\%), Australia (1.2\%) and new industrial countries: China (6.9\% of the world import), India (4.8\%), Singapore (4.0\%), United Arab Emirates (3.8\%), Thailand (2.2\%) (The World Trade Statistical Review, World Trade Organization, New York, 2016).

The most dynamically developing service sector is currently travelling abroad. After 2010 tourism sectors recovered from the crisis: exports of tourist services grew among all major exporters (with the exclusion of Malaysia - 1\%) and the import of all major importers increased (excluding Australia $-1 \%$ and Japan $-11 \%$ ), which shows the resilience of this sector. In statistical terms, "export a tourist trip" in a country like the USA means the index of the spent funds by the traveller during their stay in the USA, which includes, among others, the price of accommodation, purchased food and drinks, entertainment, local transport, gifts and other goods. EU countries (with value of 367.7 billion) were the largest exporter of travel services in this area in 2015 while for the USA this value was 178.3 billion dollars. Although the EU share in the world tourist turnover was decreasing during crisis, this fall did not apply to the southern member states. For example, in 2016 Spain was visited by a record number of tourists, i.e. 75.3 million people, bringing the country 77 billion Euro income. In 2015 in Greece 23.5 million tourists arrived, in 2016 - 27.5 million, and in 2017 more than 30 million. The proceeds from tourism in the value of 14.2 constitute in Greece the biggest part, because $24 \%$ of GDP and create 8 out of 10 new jobs.

\section{Summary and future work}

Before the crisis, the structure of international sales was influenced by the enormous demand for fuel and standardized products (petroleum, iron and steel, agricultural crops). After 2007 the development of an international division of labour has largely covered the exchange of differentiated products (textiles, clothing, office supplies). Besides there is a growing exchange of technologically advanced products, which are characterized by large scientific research work (pharmaceuticals, chemicals, telecommunication equipment). 
Given the complex nature of international exchanges, the theories must consist of several theoretical concepts, none of which can be given the most important role. The result of the division of labour in the modern world economy is the exchange of the so-called "Ricardo products" - poorly processed, allocated between countries on the basis of the relative cost of production; "Heckscher-Ohlin" products, the manufacturing of which is determined by the equipment of the countries (work, capital, technology); and "Advanced technological products" produced on the basis of human capital and modern technology, the interchange of which is determined by knowledge and technical progress. The translation of modern division of labour complicates the development of cross-exchanges within the various product categories where production allocation was often carried out within the framework of transnational corporation; this type of trade developed especially between developed and newly-industrialized countries. Due to the enormous costs of inventions, the production of new products is allocated in the country of an innovator, and when technologically advanced products become standardized, their production is reallocated to newly industrialized countries (cars and computers).

The 2007 crisis brings with it a certain qualitative change in the international space by increasing the demand for technologically advanced products, on the diversity. The rank of technologically advanced products, transport and tourism services in modern international exchanges is also growing. Increase in trade position of the so-called new industrial countries and the decline in the position of developed countries indicate the importance of a competitive factor, human capital, and diffusion of knowledge in shaping mutual trade. Although in 2007 the largest exporter in the world economy was the EU (the value of Chinese exports was lower than German), after the crisis China was promoted to the position of the largest exporter in the global economy. China's export is now higher than the EU and US exports, it is more than half of Germany's exports and three times the export of Japan. Maintaining this trend in the coming years means China's dominance in world trade exports. The ranks of new industrial countries, such as India, Korea, Mexico, Turkey and Vietnam in international trade are growing with a declining position of the US and Japan. The Central-Eastern European countries have also slightly improved their position in global exports after 2007, while there is a decrease in this value in Russia and oil countries like Saudi Arabia. As for the evolution of imports after 2007, the US remained the largest market in the world economy, ahead of the EU and China. After the crisis, the markets have increased global import of such countries as Korea, Mexico, India, United Arab Emirates, Thailand, Vietnam and Indonesia. 


\section{References}

1. Bueber, M. Sudt, T. (16.12.2012). Global R+D Funding Forecast. R\&D Magazine, pp. 1-3.

2. Rymarczyk, J., Międzynarodowe Stosunki Gospodarcze, PWN Warszawa 2010, p.277278.

3. Rynarzewski, T., Zielińska- Głębocka, A. (2006). Międzynarodowe stosunki gospodarcze. Teoria wymiany i polityki handlu międzynarodowego. Warszawa: PWN, pp. 220-221.

4. Rynarzewski, T., Zielińska-Głębocka, A. Międzynarodowe stosunki gospodarcze.

5. Salvadore, D. (1987). International Economics. New York, p. 13.

6. Stankiewicz, M.J. (2002). Konkurencyjność przedsiębiorstwa. Toruń, p. 30-31.

7. Teoria wymiany i polityki handlu międzynarodowego (2006). Warszawa: PWN.

8. The Global Competitiveness Report 2008-2009, 2015-2016 (2008, 2017). New York: World Economic Forum, Committed to Improving the State of the World.

9. The top 10 biggest $R \& D$ spenders. Fortune.com/2014/11/17/top-10-research-development.

10. The World Trade Statistical Review 2018 (2016, 2018). New York: WTO.

11. Trade MAP, International Trade Statistics. Trade Statistics for International Business Development (2007-2016).

12. Trade Statistics and Outlook (12 April 2017). World Trade Organization.

13. World Trade Organization, Press/793 Trade Statistics and Outlook (12 April 2018).

14. Wydymus, S., Głodowska, A. (2013). Handel Międzynarodowy w dobie gospodarki opartej na wiedzy. Warszawa: Difin, pp. 23-33. 